\title{
The role of distance and social networks in the geography of crowdfunding: evidence from France
}

Sylvain Dejean,

CEREGE, University of La Rochelle

\begin{abstract}
This article aims to estimate the cost of distance in the geographical flow of crowdfunding, and to show how social ties between the 94 French metropolitan regions shape the geography of funding. Our analysis draws upon a unique database provided by the French leader in rewards-based crowdfunding. The main result is that the elasticity of distance remains important (around 0.5 ), and that social ties between regions determine the flow of funding. Doubling the number of immigrants in a region increases the number of investments by $24 \%$ and reduces the impact of distance.
\end{abstract}

JEL classification: O30, R12, R23

Keywords: Crowdfunding, economic geography, gravity, social networks

\section{Introduction}

In principle, crowdfunding platforms make big promises. Freedom from the need to rely on a few institutional funders not only makes it possible to attract new funding, it also gives entrepreneurs access to information about the potential of a project, reducing uncertainties (Viotto da Cruz, 2018). They can also benefit from community expertise (Belleflamme et al., 2014), or the wisdom of backers (Mollick and Nanda, 2015). Crowdfunding also claims to democratize access to funding (Butticè and Useche, 2018; Mollick and Robb, 2016) by reducing gender inequalities (Barasinska and Schäfer, 2014; Marom et al., 2016) or offering new opportunities to fund projects with civic or public purposes (Davies, 2015). It also challenges the traditional concentration of economic activities and, by convincing a variety of distant investors to fund a project, promises to change the spatial allocation of capital (Agrawal et al., 2014; Mollick, 2014).

Informal investors include business angels and venture capitalists, who are an important resource in the early stages of a venture. At this time, a potential investor faces significant information asymmetry that can prevent him or her from accurately assessing the relevance of a project or the trustworthiness of an entrepreneur. By nature, the information needed to match entrepreneurs and the funding capacity of investors exhibits is largely tacit, especially when few signals of reliability are publicly available. The literature has shown the importance of spatial proximity in addressing this issue for the case of venture capitalists and business angels (Harrison et al., 2010; Lutz et al., 2013; 
Mason, 2007). However, the opportunity offered by crowdfunding platforms to increase global awareness of an idea, or invite feedback and comments, forces the social science researcher to reevaluate the role of distance in this new context.

At the same time, crowdfunding embodies a paradox. While, in theory, these platforms enable anyone to reach anyone else, anywhere, at any time, the vast majority of projects rely on closed social networks (Agrawal et al., 2015, 2014). The phenomenon is not new as, typically, friends and family contribute most among informal investors in the early stages of funding (Lee and Persson, 2016; Riding, 2008) and social ties are a reliable way for investors to obtain private information (Shane and Cable, 2002). However, its scale, together with the signal it sends to unknown investors, offer an opportunity to stress the precise role played by social networks in the geography of crowdfunding.

Evaluating the role of social networks as a determinant of social capital helps us to understand their importance in shaping the regional development of crowdfunding. Scholars have shown how complex, regional innovation systems rely upon local endowments in the form of social capital (Hauser et al., 2007). Dense networks, tacit knowledge, and actor proximity all help to explain why some regions are more successful than others in their ability to foster economic development (Rutten and Boekema, 2007).

This article draws upon an original dataset provided by the French leader in rewards-based crowdfunding to address two objectives. The first is to evaluate the cost of distance in the context of crowdfunding. To achieve this, we use a gravity-like equation model to aggregate individual funding decisions (about 450000 investments in 13000 projects representing 19 million euros) in France's 94 metropolitan regions, and evaluate the elasticity of distance for bilateral funding flows between these regions. In this context, information asymmetry cannot be explained by differences in language, means of payment, banking systems or consumption habits, as France is a relatively small country (it is 10 times smaller than the United States, which is the most-studied country) where people share the same culture and institutions. In this very local context, all of the conditions that are needed to make crowdfunding a financial service that reduces the cost of distance, are met.

The second objective, following Agrawal et al. (2015), Lin and Viswanathan (2015) and Mollick (2014), is to study the role of social networks in the bilateral flow of crowdfunding between French regions. To achieve this, we seek to quantify the social ties weaved between the 94 regions, based on the assumption that underlying social networks support inter-regional investments. Drawing upon data from the 2013 Census, we create a variable that describes social bonds between two regions, based on residential migration statistics. Specifically, data describing how many people born in region $i(j)$ live in region $j(i)$ is used as evidence of a set of interpersonal resources that can be mobilized by users of crowdfunding platforms.

The main finding is that the elasticity of distance remains significant (around 0.5 ) in the context of reward-based crowdfunding platforms. We also find that inter-regional social ties determine the flow of funding (doubling the number of immigrants in a particular region increases the number of investments by $24 \%$ ), and also significantly reduces or even cancels out (under certain conditions) the impact of geographical distance. 
The remainder of this article is structured as follows; first, we present the theoretical background concerning the impact of distance and social networks on crowdfunding. We then describe the gravity equation model and the dataset before turning to our findings. Finally, we conclude with a discussion of the scope and limits of our approach.

\section{Theoretical background}

\section{Why distance matters in crowdfunding}

Using a dataset of 109 business angels in the United Kingdom, Harrison et al. (2010) showed that only $24 \%$ of their investments could be considered distant, which is consistent with findings from Canada and Finland (Lumme et al., 2013; Riding et al., 1993). Results are more nuanced when considering venture capitalists. Fritsch and Schilder (2008), for instance, studied 85 German financiers, and concluded that the need for spatial proximity was overestimated. However, in the same context, Lutz et al. (2013) showed that spatial proximity proxied by journey time had an impact on the likelihood of closing a financing round between venture capitalists and German portfolio companies.

According to Mason (2007), various reasons can explain the persistent effect of distance on informal investment. The first concerns awareness of opportunities, meaning that an investor tends to rely on their immediate environment to find business opportunities. The second is related to the ability of investors to trust the entrepreneur; this issue is particularly salient when funding small-scale ventures or individual entrepreneurs, where success relies on the skills and involvement of a few people. Agency costs are a third factor thought to explain the importance of distance (Landström, 1992). The cost of monitoring investments increases with distance, deterring investors from investing in riskier projects.

The emergence of crowdfunding has expanded opportunities to finance all categories of ventures, but it is of particular interest for the youngest and smallest ones that are neglected by venture capitalists and business angels. The literature cited above argues that informal investors are also sensitive to spatial proximity; therefore, the question of whether crowdfunding is able to reduce the impact of distance depends on their ability to change the way information is acquired and shared by investors and entrepreneurs.

It is clear that crowdfunding offers new opportunities to signal the existence of a project. From a backer's perspective, it makes no difference if an entrepreneur is local or distant - funding requests are considered in terms of their level of interest, while herding behavior is at least as important as geographical considerations. Consequently, crowdfunding is expected to reduce the distance between funders and project developers by raising awareness of remote, small ventures and individual entrepreneurs.

Crowdfunding seems to have a limited effect on agency costs. On the one hand, platforms enable a wide variety of interactions between the project developer and the crowd who funded him or her. News and progress updates, advice and feedback from the crowd, comments, messages, and questions are some of the many ways to control, monitor and align the interests of an investor and 
the entrepreneur during the development of the venture. However this ability to exercise distant control or influence the entrepreneur is incomplete and, following Strausz, (2017), unlikely to decrease agency costs as such costs have to be absorbed by each backer. As a result, the net effect of crowdfunding platforms is probably very low and consequently, their ability to reduce the cost of distance.

Trust, knowledge, expertise and experience are all forms of tacit knowledge. As such, this is not easily codifiable and partly immune from digitalization or sharing over telecommunication networks. In this context, proximity or even face-to-face interaction is necessary to internalize these externalities (Audretsch and Feldman, 1996; Storper and Venables, 2004). Although crowdfunding platforms provide various ways to collect information about the project founder, such as his/ her previous experience, motivations, and details about the project, tacit knowledge remains important in establishing trust and mutual commitment. Burtch et al. (2014) highlighted the importance of cultural distance between lenders and borrowers on a peer-lending platform, and underlined that cultural differences also helped to explain the persistent effect of distance. Similarly, Lin and Viswanathan, (2015) investigated the preference for home-based investment on Prosper, a pioneering crowdlending platform. Their work drew upon three experimental designs to understand the reasons underlying the persistence of home bias. They concluded that the effect can only be driven by emotional reasons, which once again highlights the importance of investors and entrepreneurs sharing non-codifiable information. In Australia, Guenther et al. (2018) studied an equity-based crowdfunding platform, and found a negative correlation between distance and a backer's decision to invest. Their results suggest that the behavior of the crowd is similar to that of venture capitalists, despite the opportunities offered by the platform.

Our study focuses on reward-based crowdfunding. Many of the projects found on these platforms are dedicated to cultural activities (Mollick, 2014), and shared norms, culture or history between backers and project owners undoubtedly reinforce the role of non-codifiable information. Consequently, we expect to find little reduction in the cost of distance in this context.

\section{The role of social networks in crowdfunding}

Crowdfunding platforms are the first to recognize that relying on relatives to finance a project is a necessary and sometimes sufficient condition. Consequently, Ulule, the French leader in rewardbased crowdfunding has separated potential investors into three circles ${ }^{1}$. The first two are family and friends, and friends of friends, while the third consists of unknown people. Ulule states, "Most small and medium-sized projects can be financed exclusively from your first and second network circles" or, put another way, the social network of the project developer is a key resource in fundraising.

Agrawal et al. (2015) demonstrated the importance of social networks on funding decisions in a study of the pioneering crowdfunding platform SellABand. Their investigation of the timing of investments, and investors' characteristics found that distant funders use early investments by locals as a signal of

${ }^{1}$ https://community.ulule.com/topics/-3-crowfunding-circles-881/ 
quality. They also showed that most local investors are friends and family. After controlling for the social networks of founders, distance no longer influenced the decision to invest.

The importance of the social network structure of entrepreneurs is also emphasized in Zheng et al. (2014), who demonstrated that the number of social network ties has a positive impact on a funding campaign, both in the United States and China. This result echoes the work of Mollick (2014) who found that the chance of success increases with the size of the social network. The role of social ties does not end in the preexisting social networks of project developers - they can also be built within platforms by ongoing interactions with its community (Butticè et al., 2017). Based on a large sample of projects on Kickstarter, Colombo et al. (2015) showed that so-called 'internal' social capital allows entrepreneurs to attract early backers. Finally, research by Giudici et al. (2018) found that the characteristics of a geographical area, such as local altruism or local social capital positively impacted funds raised from the crowd of internet users.

However, with the exception of Agrawal et al. (2015), little research has addressed the question of the impact of the social networks of project owners on the geography of crowdfunding. The question is challenging, as we need to measure the extent to which people who live in different geographical areas share the same social networks. Ideally, we would have access to data about each backer's relationship with the entrepreneur, as in Agrawal et al. (2015). But the latter study only looked at a couple of projects, and the method is impossible to generalize to the 13000 projects in our study. Instead, and inspired by the literature on knowledge diffusion (Agrawal et al., 2008; Lissoni, 2018) we used residential migration as a proxy for inter-regional social ties. The social networks of inventors, researchers or workers can support very different exchanges at very different geographical levels, from the flow of knowledge (Agrawal et al., 2006), to international technological transfers (Kerr, 2008), and even inter-regional trade (Combes et al., 2005). Reward-based crowdfunding reflects individual entrepreneurship or small ventures led by a few individuals, and the crowd of backers is not, by definition, made up of finance professionals. Using a measure of inter-regional migration provides a picture of social connections and, thus, distant funding opportunities.

All of the studies presented above demonstrate the importance of entrepreneurs' social capital and, especially, the role played by the resources that constitute their social networks. If, as we think, we are able to proxy social ties between inhabitants of the 94 French metropolitan regions, we expect that they will shape the bilateral flow of funding and, consequently, reduce the impact of geographical distance.

\section{The gravity model}

We adopted a modified version of the gravity equation model to study the role of distance and the impact of social networks on the flow of crowdfunding between French regions. Initially developed to study the determinants of international trade (Anderson, 1979; Bergstrand, 1985) gravity models have been used to study exchanges in different contexts, including e-commerce (Blum and Goldfarb, 2006; Hortaçsu et al., 2009; Lendle et al., 2012) and, more recently, lending-based crowdfunding (Burtch et al., 2014). Like Newton's theory of gravity, the equation considers that the relationship between two entities is proportional to their size and inversely related to the distance between 
them. In this article, we consider the flow of crowdfunding from region $j$ to region $i$. Funds are aggregated individual investments in different projects.

The model is specified as follows:

$$
\begin{aligned}
& \ln \left(F_{i j}+1\right)=\alpha_{1}-\alpha_{2} \ln \left(\text { distance }_{i j}\right)+\alpha_{3} \ln \left(\text { Wealth }_{i} \times \text { Wealth }_{j}\right)+\alpha_{4} \ln \left(\text { density }_{i} \times\right. \\
& \text { density } \left._{j}\right)+\alpha_{5} \ln \left(\text { creativ }_{i} \times \text { creativ }_{j}\right)+\alpha_{6} \ln \left(\text { migrori }_{i j}\right)+\alpha_{7} \ln \left(\text { migrdest }_{j i}\right)+\varepsilon_{i j}
\end{aligned}
$$

Where $F_{i j}$ is the number of investments from region $j$ to region $i$. In this first specification, we control for economic variables that are assumed to impact the propensity of a region to generate online exchanges via a crowdfunding platform. The variable $W E A L T H_{i(j)}$ is a proxy for the size of the economy and wealth of the population of region $i(j)$. It is calculated by multiplying median disposable income by the region's population. The variable $D E N S I T Y_{i(j)}$ is a measure of the population per unit area $\left(\mathrm{km}^{2}\right)$ in the region $i(j)$ and captures differences in urbanization. Many rewards-based crowdfunding platforms specialize in cultural projects (Mollick, 2014) and, to account for this, we include the proportion of the active population employed in the cultural and arts sectors as a proxy for local skills in the creative industries (CREATIV $i$ and $\left.C R E A T I V_{j}\right)$. This variable also represents an opportunity to indirectly account for the impact of the creative classes (Florida, 2005) on the regional success of crowdfunding.

Our strategy of taking into account the impact of social networks is based on Combes et al. (2005), who estimate the economic effect of migrants in metropolitan French regions. We define MIGRORI $I_{i j}$ as the number of people living in region $i$ but born in region $j$, respectively, while MIGRDEST $j$ are those who live in region $j$ but were born in region $i$. Although both variables define the social networks that link different French regions, they have potentially different implications. MIGRORI ${ }_{i j}$ are immigrants: in the context of our work, this variable reflects the ability of project founders to mobilize the social network in his or her region of origin. Inversely, MIGRDEST $T_{j i}$ are emigrants: potential investors do so because of the social ties with their region of origin.

In a second step, we consider a fixed-effects model that takes into account all region-specific characteristics that may influence the flow of funding. As region-specific variables are dropped from the estimation, the model takes the following form:

$$
\ln \left(F_{i j}+1\right)=\alpha_{1}+\alpha_{2} \ln \left(\text { distance }_{i j}\right)+\eta_{i}+\eta_{j}+\varepsilon_{i j}
$$

Where $\eta_{i}$ and $\eta_{j}$ are unobserved characteristics of regions $i$ and $j$.

We estimate these models by ordinary least squares (OLS) using a standard log-linearized equation. The drawback of this method is that estimates are inefficient in the presence of heteroscedasticity and consider observations when the dependent variable equals zero. We deal with the latter issue by using $\ln \left(F_{i j}+1\right)$ as the dependent variable, although the actual number of zeros in the sample is moderate (10\%). The issue of heteroscedasticity is discussed in different robustness tests, and presented in section 5 . 


\section{Data}

Estimates of the model described above are based on a database provided by Ulule, the French (and European) leader in rewards-based crowdfunding. Since its launch in 2010, the platform has funded more than 17000 projects with a value of more than $€ 78$ million. For the present article, the platform provided us with full details for the period 2012-2015; these 15000 projects represent one million investments with a value of $€ 35$ million. Non-French projects and funds were discarded from the dataset, together with aberrant observations, leaving 14800 projects funded by 732686 contributions.

An important point to note is that geographical identification is not mandatory for subscription to the platform, neither for the founder of a project nor for backers who decide to invest. Nevertheless, it was available for $87 \%(12887)^{2}$ of projects and $62 \%$ (452 850) of contributions, with a total value of $€ 19$ million. We are aware that this is a potential limitation; however, it is only a concern if there is selection bias in the location of funders. This issue, which is discussed in section 6 , seems to have very limited consequences for our results.

Users who do declare their location provide a postal code. The two first digits of this code identify the region in France. This information is used to construct the dependent variable, namely the number of investments provided by backers to project founders, for the period 2012-2015. As Table $1 \mathrm{~b}$ shows, mean inter-regional contributions were 33.3. Standard errors were high, suggesting strong heterogeneity in the distribution (for instance, in $9.7 \%$ of regions, bilateral funding equaled zero). Intra-regional investment (when the backer and founder live in the same region) is an important contributor to total funding, representing $28 \%$ of the total number of investments and $29 \%$ of the value.

The French département is our unit of analysis. To simplify the analysis, and because this geographical unit is specific to France, here we refer to it as a "region". There are 94 such units. The département is an administrative division of France; it was created in 1790 and, as Combes et al. (2005) highlight, this spatial delimitation is not neutral and shapes economic activities and social networks at the national level.

The key variables for our demonstration are two representative, regional social networks based on data from the 2013 Census provided by the National Institute of Statistics. Specifically, we drew upon the Residential migration: location of city of residence and city of prior residence database. This dataset provides details of 19 million French residents at the time of the census and their region of birth. Each individual is weighted according to his or her weight in the overall population. These data made it possible to build a matrix of inter-regional migration based on estimates of the number of people born in region $i(j)$ and living in region $j(i)$ in 2013. The legitimacy of using these variables as a proxy for the geographical pattern of social networks lies in their ability to provide a picture of the stock of social ties that individuals in a particular region have accumulated. Obviously, only considering the region of birth and current residence does not provide a full picture, as people may have lived in many different regions between their birth and 2013, and can also have spent little time

${ }^{2}$ Descriptive statistics of the 12887 crowdfunding campaigns are available in Table 1a. 
in either of the two regions. However, we do, at least, know that a social connection exists and, given the size of the sample (and its adjustment over the whole population), we can be confident in the ability of our matrix to provide, on average, a faithful picture of regional migration.

According to the descriptive statistics given in Table 1b, and consistent with Combes et al. (2005), the average percentage of migrants, per region, was $0.4 \%$ and the percentage of the population still living in the region where they were born was $51.4 \%^{3}$.

Figure 1a to 1c show spatial patterns of the main variables. These figures show the geographical distribution of crowdfunding, immigrants and emigrants for three French regions, selected to highlight different patterns. The Rhône-Alpes region (Fig. 1a) hosts the regional metropolis of Lyon, which is the third-biggest city in France. The Paris region (Fig. 1b) highlights a disproportionate number of crowdfunding projects, while the Finistère region (Fig. 1c) is the westernmost region in France with a strong cultural identity. Overall, Figure 1 shows a clear correlation between migration and crowdfunding flows in the three regions. Inward funding appears, at first sight, to be less concentrated around the region of destination than the flow of migrants, which appears to more closely related to spatial proximity. This higher dispersion of crowdfunding flows seems to be partly driven by the biggest cities in France (Toulouse, Bordeaux and Marseille), which concentrate a high number of potential backers. A variety of migratory patterns are seen for different regions (this is especially true for Rhône-Alpes), suggesting the existence of distinct social networks and thus a potential differential impact on bilateral funding.

Regional population, disposable income and population density figures were supplied by the French Institute of Statistics for the year 2015. Finally, the distance between two regions was estimated as the geodesic distance in kilometers between the biggest cities in each region.

\section{Findings}

Table 2 shows the results of OLS estimates of regional bilateral crowdfunding excluding intra-regional investments, making this specification closer to the canonical gravity model. Columns (1) and (2) estimate the model without the effect of social networks. The elasticity of distance is around 0.5 , suggesting that doubling the distance between two regions divides the number of investments by two. At first sight, this finding seems important, given the factors presented in the introduction notably the lack of shipping costs or significant cultural differences between French regions. As a comparison, using international trade data collected from E-bay, Lendle et al. (2012) found elasticity of between 0.35 and 0.5 (depending on their specification), while Hortaçsu et al. (2009) used a comparable sample (but only considered intra-country trade), and found much lower elasticity of between 0.05 and 0.1 . This result confirms the existence of important information-related costs in the choice of funding a project, and the inability of the platform to disseminate this information online.

${ }^{3}$ Combes et al. (2005) studied worker migration and found average percentages of $0.5 \%$ and $52.6 \%$ respectively. 
Introducing variables related to regional migration (to account for the existence of regional social networks) significantly reduced the elasticity of distance. This provides support for the idea that social ties are a means to convey the trust needed to generate contributions in crowdfunding projects. Columns (3) and (4) show the result when adding immigrant and emigrant networks. Although the elasticity of distance decreases sharply, the network of immigrants (i.e. those who live in the region where the project is proposed and were born in the region where funds originate) has a stronger positive impact on bilateral investments than the network of emigrants. In other words, the impact of social networks is higher when the flow of funding follows the migration of individuals. Interestingly when both networks (immigrants and emigrants) are included in the regression (column 5) the effect of distance almost disappears and is no longer significant.

Table 3 incorporates intra-regional funding by adding the variable HOME (a dummy which equals one when the funder and the founder are in the same region) in the estimate. The elasticity of distance is close to that shown in Table 2 and approaches zero when taking into account the impact of social networks. The most striking result is the magnitude of the home effect. In the more complete specifications (columns 2 to 5 ) being in the same region increases the number of funders by $300-$ $400 \%$. This 'primacy' given to the very close proximity of funders and project developers suggests a strong non-linearity in the effect of distance, even when controlling for the existence of social networks. Being located in the same region undoubtedly increases the probability of direct or indirect social interactions with the project developer, reducing uncertainly about the viability of the project. It also increases the probability of local impacts (e.g. opening a bar, a service activity or promoting a local project with high social value). Once the regional border is crossed, distance has a very limited impact when controlling for potential social relationships between funders and project developers.

The other dependent variables likely to have an impact have the expected effect whatever the specification. The number of funders between two regions increases with the wealth of the population, the density of the region, and the percentage of employees working in the arts and creative industries.

Table 4 shows the result of the fixed-effects specification. Introducing dummies for region of origin and destination captures all specific effects. The results are consistent with the other specifications. Doubling the number of immigrants increases the number of funders by $25 \%$, compared to $17 \%$ when doubling the number of emigrants. The effect of distance remains (negatively) significant with an elasticity of -0.05 .

As projects were divided into 15 categories, we were able to estimate our model for each category. Table 5 provides the estimate for some of these categories, notably the biggest in terms of volume of projects. It should be noted that categories were self-determined by the owner of the project who was able to associate a tag proposed by the platform with his/ her project. The results suggest that elasticities of distance as well as the magnitude of the effect of social networks vary within categories. Although it is difficult to draw any general conclusions for individual categories, some results can be highlighted. The impact of social networks seems to be more important for the 'charity' and 'music' categories than for the 'comics' or 'stage' categories, suggesting that the former are more dependent on social ties than the latter. We also note that funding in the charity and music 
categories is more impacted by the emigrant than the immigrant social network. A clear home bias is seen for the stage category, and the elasticity of distance is high. This finding may be explained by the nature of these projects, which are produced and consumed locally. Another interesting result appears in column 6 of Table 5 where we only consider projects concerning pre-ordered goods (mainly comics, music albums or craft items). In this case, both distance and social networks have a very limited effect on the flow of funding, which can be explained by the fact that these pre-ordered goods are standardized or, at least, ready to be produced. Here, there is less dependence on trust, and information asymmetry has less impact, meaning that for these categories of 'less' informationrelated goods, the cost of distance may be significantly reduced.

Although we should be cautious about these interpretations, especially for categories that only contain a few hundred projects, the results suggest that the characteristics of projects are consistent with different geographical patterns.

\section{Robustness}

Table 6 presents estimates based on the amount of funding as the dependent variable; $A_{i j}$ is the amount transferred from region $j$ to region $i$. Columns 1 and 2 can be compared respectively with columns 1 and 5 in Table 3 and column 4 in Table 4. The results show that considering the amount of funding, rather than the number of funders does not change the result, and only marginally changes elasticities. The main difference is that the coefficient associated with the social network is higher, and the log of distance remains non-significant even in the fixed-effect specification.

The impact of the region of Paris is a concern and a potential source of heteroscedasticity. The predominance of the capital of the French economy is well known. Paris and its surroundings represent $3.4 \%$ of the total population, but concern $11.7 \%$ of the projects in our dataset. It is also where employment in the creative industries is concentrated ( $11.4 \%$ of the active population compared to the national mean of $1.5 \%$ ). Seventeen percent of funding goes to Paris and $11 \%$ originates from it. For economic reasons, the region is very attractive for workers. Therefore, we estimated the gravity model excluding central Paris and its surrounding Ile-de-France region ${ }^{4}$, to ensure the robustness of our main findings. The results are presented in Table 7. It is clear that they are comparable with those given in Table 3 despite slight differences. Notably, the effect of distance remains significant after the introduction of regional social tie variables and the home effect is less significant, which confirm the attraction of Paris and its surrounding regions. However, the coefficient associated with the social network variable is unchanged.

\section{Conclusion and discussion}

Our results are some of the first to address the spatial consequences of crowdfunding. Estimating the effect of distance on regional flows, using a gravity equation model revealed that distance plays an important role. This result contrasts with the context of 'local' crowdfunding, which seems to favor the disappearance of the distance effect. The introduction of variables to account for the existence of

\footnotetext{
${ }^{4}$ This region is composed of 8 French départements.
} 
social networks between French regions showed that potential ties between the inhabitants of two regions not only increased the number of funders and the amount of funding, but also significantly lessened the negative impact of distance. Before discussing the implications of our main findings, we first discuss the potential limitations of our results.

It is clear that factors other than social networks between regions can explain the correlation between the migration of individuals and the flow of crowdfunding. People seek job opportunities and thus choose to relocate to areas where economic activity is growing. These are also the areas where ideas and projects emerge, making them a natural destination for funding. However, the fact that our result is robust to fixed-effects model limits the possibility that omitted variables or endogeneity would weaken our findings.

As mentioned in section 3, we were only able to consider $67 \%$ of the database's contents. This is because users do not have to declare their location to make a contribution. Does this have an impact on our results? Is it evidence of a selection bias (i.e. is a user who declares his/ her location different from another who does not)? A way to control for this potential bias is to compare the two subsamples using a common attribute. The distribution of contributions appears to be a good candidate. A comparison of the means and standard deviation of these two samples (with and without declared localization) is presented in Table 8 and reveals no significant difference in means, but a significant difference in standard errors.

However, although the standard deviation is lower for the subsample used in this article, it seems unlikely that it hides a significant difference in the nature, motivation or location of contributions. Another way to highlight differences with and without localization samples is to use the tag or category associated with each project. Here, the main categories (music, film and video, stage, publishing) are present in the same proportions in the two subsamples. The only difference comes from the under-representation of contributions made to projects categorized as charity (respectively $14 \%$ and $19 \%$ of the sample with and without declared localization) and an over representation of contributions made to games and comics ( $90 \%$ of investments in these two categories are geographically localized). Nevertheless, as these categories only represent $10 \%$ of all projects and there is no difference in the mean amount contributed between the two subsamples, we can be confident that our results are only weakly affected by the non-systematic declaration of localization.

As the introduction to this article highlights, the rise of crowdfunding is concomitant with various promises. Among them is the hope of the democratization of access to funding. A corollary is that the place where a project is developed matters less in a world where crowdfunding exists. Our results tend to mitigate this assertion: funding flows are higher between wealthy regions and nothing suggests that crowdfunding platforms increase opportunities for less-dynamic areas. Like the migration of populations, financial exchanges partly reflect the geography of social networks. The fact that two regions have a high level of bilateral contributions when they share a migration history suggests that platform users are looking for projects with which they have an emotional connection. Social ties, but also a regional attachment or a distant relationship with a particular community can drive these emotions. Some links between regions are obviously due to a shared cultural history or geographical proximity, but others can be the consequence of a historical industrial relationship or even the existence of infrastructure that facilitates inter-regional mobility. All of this information can 
help to understand the motivations that drive funding between two regions and, consequently, how crowdfunding helps to create new geographical access to capital.

We must also keep in mind that the rewards-based crowdfunding is mainly aimed at 'cultural' projects, i.e. those where information asymmetry is consubstantial to their nature. Digital platforms have clearly fluidized exchanges and, in our case, financial contributions. However, for many information-intensive interactions, it is likely that they fail to deeply modify opportunities for market protagonists. When asking the crowd to fund a project, it seems more accurate to claim that crowdfunding platforms have helped to concretize latent interactions, rather than creating and extending the field of possibilities. 


\section{References}

Agrawal, A., Catalini, C., Goldfarb, A., 2015. Crowdfunding: Geography, Social Networks, and the Timing of Investment Decisions. Journal of Economics \& Management Strategy 24, 253-274. https://doi.org/10.1111/jems.12093

Agrawal, A., Catalini, C., Goldfarb, A., 2014. Some Simple Economics of Crowdfunding. Innovation Policy and the Economy 14, 63-97. https://doi.org/10.1086/674021

Agrawal, A., Cockburn, I., McHale, J., 2006. Gone but not forgotten: knowledge flows, labor mobility, and enduring social relationships. Journal of Economic Geography 6, 571-591.

Agrawal, A., Kapur, D., McHale, J., 2008. How do spatial and social proximity influence knowledge flows? Evidence from patent data. Journal of Urban Economics 64, 258-269. https://doi.org/10.1016/j.jue.2008.01.003

Anderson, J.E., 1979. A Theoretical Foundation for the Gravity Equation. The American Economic Review 69, 106-116.

Audretsch, D.B., Feldman, M.P., 1996. R\&D Spillovers and the Geography of Innovation and Production. The American Economic Review 86, 630-640.

Barasinska, N., Schäfer, D., 2014. Is Crowdfunding Different? Evidence on the Relation between Gender and Funding Success from a German Peer-to-Peer Lending Platform. German Economic Review 15, 436-452. https://doi.org/10.1111/geer.12052

Belleflamme, P., Lambert, T., Schwienbacher, A., 2014. Crowdfunding: Tapping the right crowd. Journal of Business Venturing 29, 585-609. https://doi.org/10.1016/j.jbusvent.2013.07.003

Bergstrand, J.H., 1985. The Gravity Equation in International Trade: Some Microeconomic Foundations and Empirical Evidence. The Review of Economics and Statistics 67, 474-481. https://doi.org/10.2307/1925976

Blum, B.S., Goldfarb, A., 2006. Does the internet defy the law of gravity? Journal of International Economics 70, 384-405. https://doi.org/10.1016/j.jinteco.2005.10.002

Burtch, G., Ghose, A., Wattal, S., 2014. Cultural Differences and Geography as Determinants of Online Pro-Social Lending. MIS Quaterly 38, 773-794.

Butticè, V., Colombo, M.G., Wright, M., 2017. Serial Crowdfunding, Social Capital, and Project Success. Entrepreneurship Theory and Practice 41, 183-207. https://doi.org/10.1111/etap.12271

Butticè, V., Useche, D., 2018. Crowdfunding to overcome the liability of outsidership: Drivers of immigrant entrepreneurs' fundraising performance.

Colombo, M.G., Franzoni, C., Rossi-Lamastra, C., 2015. Internal Social Capital and the Attraction of Early Contributions in Crowdfunding. Entrepreneurship Theory and Practice 39, 75-100. https://doi.org/10.1111/etap.12118

Combes, P.-P., Lafourcade, M., Mayer, T., 2005. The trade-creating effects of business and social networks: evidence from France. Journal of International Economics 66, 1-29. https://doi.org/10.1016/j.jinteco.2004.07.003

Davies, R., 2015. Three provocations for civic crowdfunding. Information, Communication \& Society 18, 342-355. https://doi.org/10.1080/1369118X.2014.989878

Florida, R., 2005. Cities and the Creative Class. Routledge. 
Fritsch, M., Schilder, D., 2008. Does Venture Capital Investment Really Require Spatial Proximity? An Empirical Investigation. Environ Plan A 40, 2114-2131. https://doi.org/10.1068/a39353

Giudici, G., Guerini, M., Rossi-Lamastra, C., 2018. Reward-based crowdfunding of entrepreneurial projects: the effect of local altruism and localized social capital on proponents' success. Small Bus Econ 50, 307-324. https://doi.org/10.1007/s11187-016-9830-x

Guenther, C., Johan, S., Schweizer, D., 2018. Is the crowd sensitive to distance?-how investment decisions differ by investor type. Small Bus Econ 50, 289-305.

https://doi.org/10.1007/s11187-016-9834-6

Harrison, R., Mason, C., Robson, P., 2010. Determinants of long-distance investing by business angels in the UK. Entrepreneurship \& Regional Development 22, 113-137.

https://doi.org/10.1080/08985620802545928

Hauser, C., Tappeiner, G., Walde, J., 2007. The Learning Region: The Impact of Social Capital and Weak Ties on Innovation. Regional Studies 41, 75-88. https://doi.org/10.1080/00343400600928368

Hortaçsu, A., Martínez-Jerez, F.A., Douglas, J., 2009. The Geography of Trade in Online Transactions: Evidence from eBay and MercadoLibre. American Economic Journal: Microeconomics 1, $53-$ 74. https://doi.org/10.1257/mic.1.1.53

Kerr, W.R., 2008. Ethnic Scientific Communities and International Technology Diffusion. The Review of Economics and Statistics 90, 518-537. https://doi.org/10.1162/rest.90.3.518

Landström, H., 1992. The relationship between private investors and small firms: an agency theory approach. Entrepreneurship \& Regional Development 4, 199-223. https://doi.org/10.1080/08985629200000012

Lee, S., Persson, P., 2016. Financing from Family and Friends. Rev Financ Stud 29, 2341-2386. https://doi.org/10.1093/rfs/hhw031

Lendle, A., Olarreaga, M., Schropp, S., Vézina, P.-L., 2012. There Goes Gravity: How Ebay Reduces Trade Costs (SSRN Scholarly Paper No. ID 2153544). Social Science Research Network, Rochester, NY.

Lin, M., Viswanathan, S., 2015. Home Bias in Online Investments: An Empirical Study of an Online Crowdfunding Market. Management Science 62, 1393-1414. https://doi.org/10.1287/mnsc.2015.2206

Lissoni, F., 2018. International migration and innovation diffusion: an eclectic survey. Regional Studies 52, 702-714. https://doi.org/10.1080/00343404.2017.1346370

Lumme, A., Mason, C., Suomi, M., 2013. Informal Venture Capital: Investors, Investments and Policy Issues in Finland. Springer Science \& Business Media.

Lutz, E., Bender, M., Achleitner, A.-K., Kaserer, C., 2013. Importance of spatial proximity between venture capital investors and investees in Germany. Journal of Business Research 66, 23462354. https://doi.org/10.1016/j.jbusres.2012.04.016

Marom, D., Robb, A., Sade, O., 2016. Gender Dynamics in Crowdfunding (Kickstarter): Evidence on Entrepreneurs, Investors, Deals and Taste-Based Discrimination (SSRN Scholarly Paper No. ID 2442954). Social Science Research Network, Rochester, NY.

Mason, C.M., 2007. Informal Sources of Venture Finance, in: Parker, S. (Ed.), The Life Cycle of Entrepreneurial Ventures, International Handbook Series on Entrepreneurship. Springer US, Boston, MA, pp. 259-299. https://doi.org/10.1007/978-0-387-32313-8_10 
Mollick, E., 2014. The dynamics of crowdfunding: An exploratory study. Journal of Business Venturing 29, 1-16. https://doi.org/10.1016/j.jbusvent.2013.06.005

Mollick, E., Nanda, R., 2015. Wisdom or Madness? Comparing Crowds with Expert Evaluation in Funding the Arts. Management Science 62, 1533-1553. https://doi.org/10.1287/mnsc.2015.2207

Mollick, E., Robb, A., 2016. Democratizing Innovation and Capital Access: The Role of Crowdfunding: California Management Review. https://doi.org/10.1525/cmr.2016.58.2.72

Riding, A., Canada, Ontario (Eds.), 1993. Informal investors in Canada: the identification of salient characteristics. Carleton University, School of Business, Faculty of Social Sciences, Ottawa, ON.

Riding, A.L., 2008. Business angels and love money investors: segments of the informal market for risk capital. Venture Capital 10, 355-369. https://doi.org/10.1080/13691060802351222

Rutten, R., Boekema, F., 2007. Regional social capital: Embeddedness, innovation networks and regional economic development. Technological Forecasting and Social Change 74, 18341846. https://doi.org/10.1016/j.techfore.2007.05.012

Shane, S., Cable, D., 2002. Network Ties, Reputation, and the Financing of New Ventures. Management Science 48, 364-381. https://doi.org/10.1287/mnsc.48.3.364.7731

Storper, M., Venables, A., 2004. Buzz: face-to-face contact and the urban economy. Journal of Economic Geography 4, 351-370.

Strausz, R., 2017. A Theory of Crowdfunding: A Mechanism Design Approach with Demand Uncertainty and Moral Hazard. American Economic Review 107, 1430-1476. https://doi.org/10.1257/aer.20151700

Viotto da Cruz, J., 2018. Beyond financing: crowdfunding as an informational mechanism. Journal of Business Venturing. https://doi.org/10.1016/j.jbusvent.2018.02.001

Zheng, H., Li, D., Wu, J., Xu, Y., 2014. The role of multidimensional social capital in crowdfunding: A comparative study in China and US. Information \& Management 51, 488-496.

https://doi.org/10.1016/j.im.2014.03.003 
Figure 1a: Geographical patterns of funding and migration in the Rhône-Alpes region

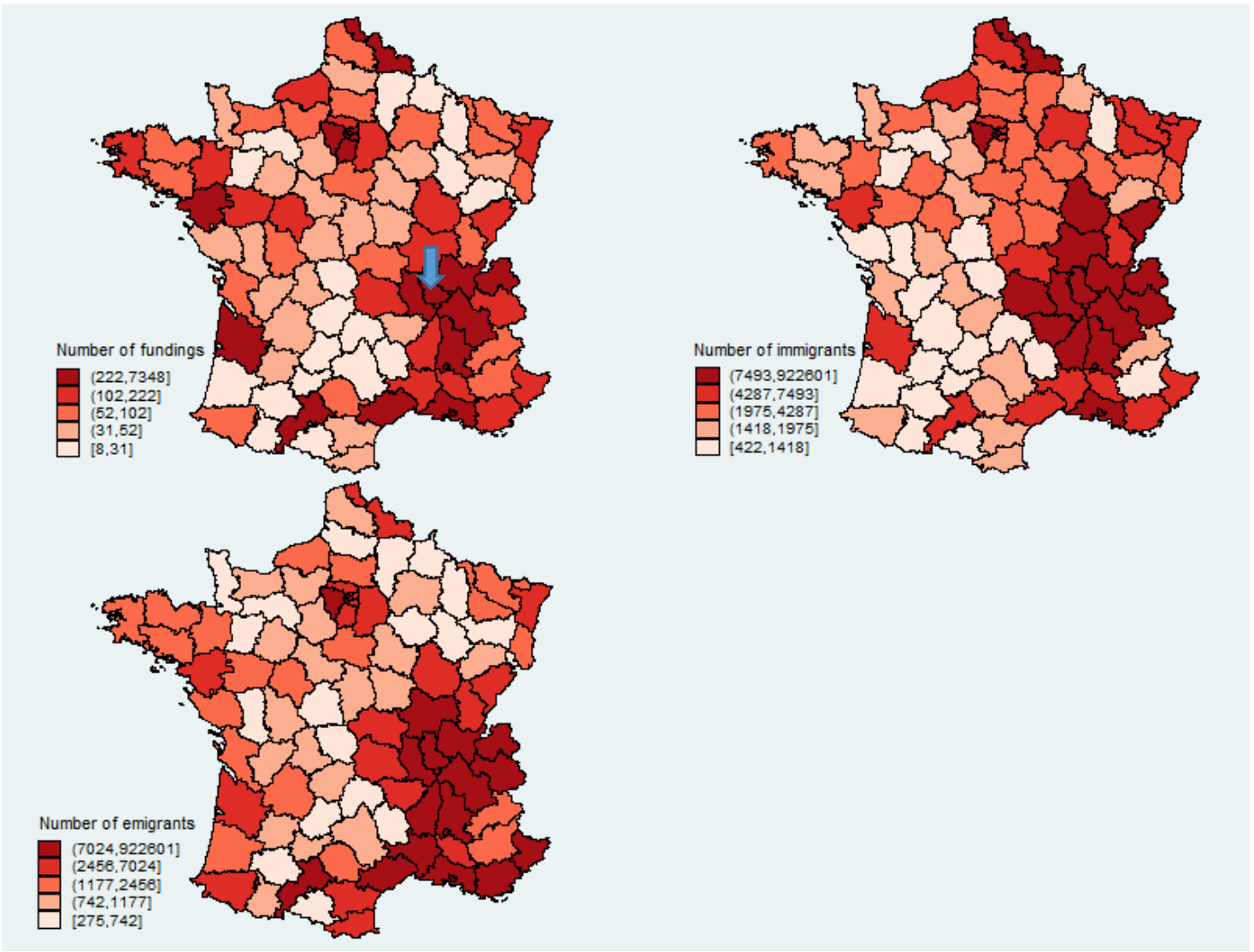

Figure 2b: Geographical patterns of funding and migration in the Paris region

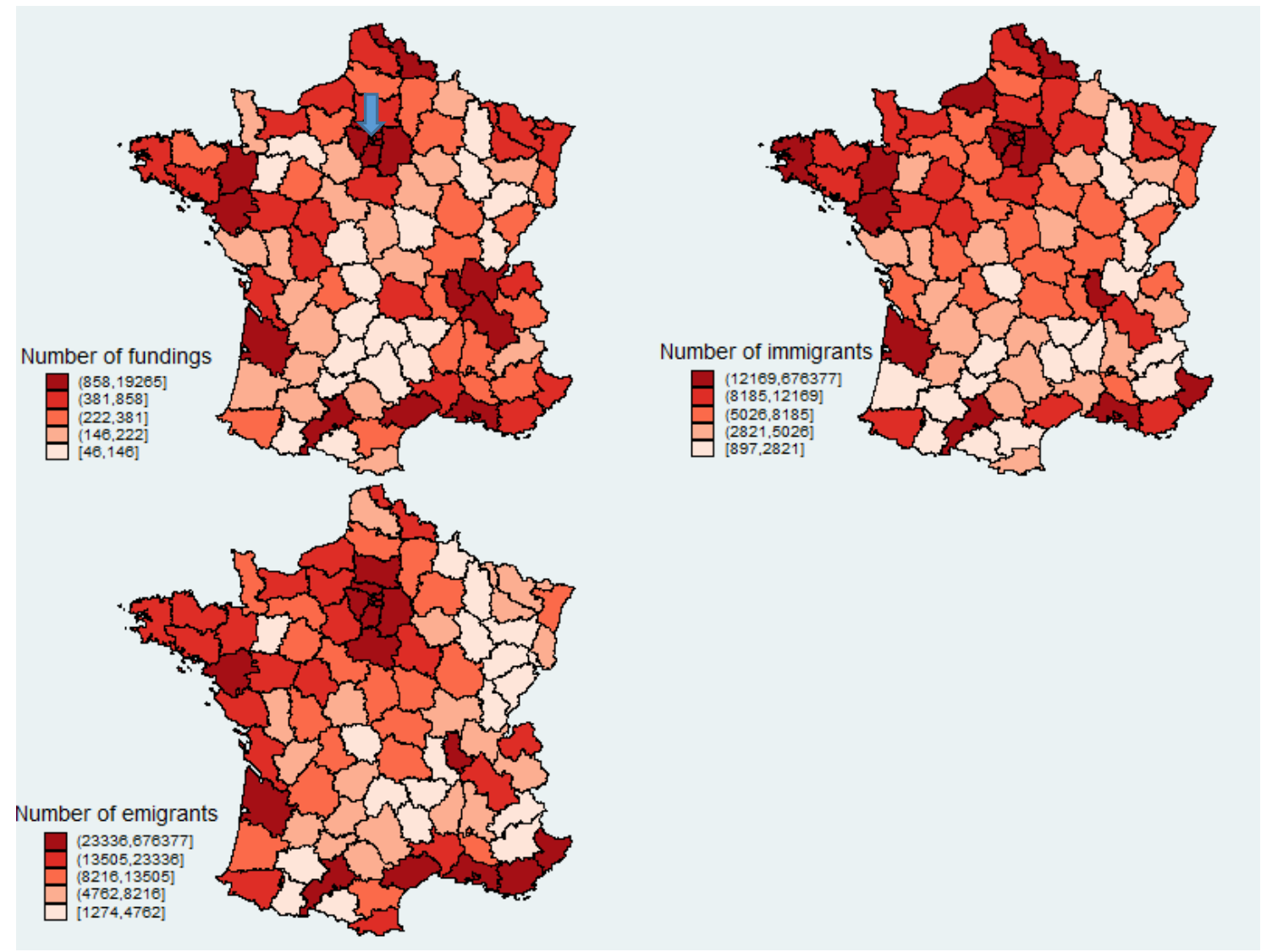


Figure 3c: Geographical patterns of funding and migration in the Finistère region

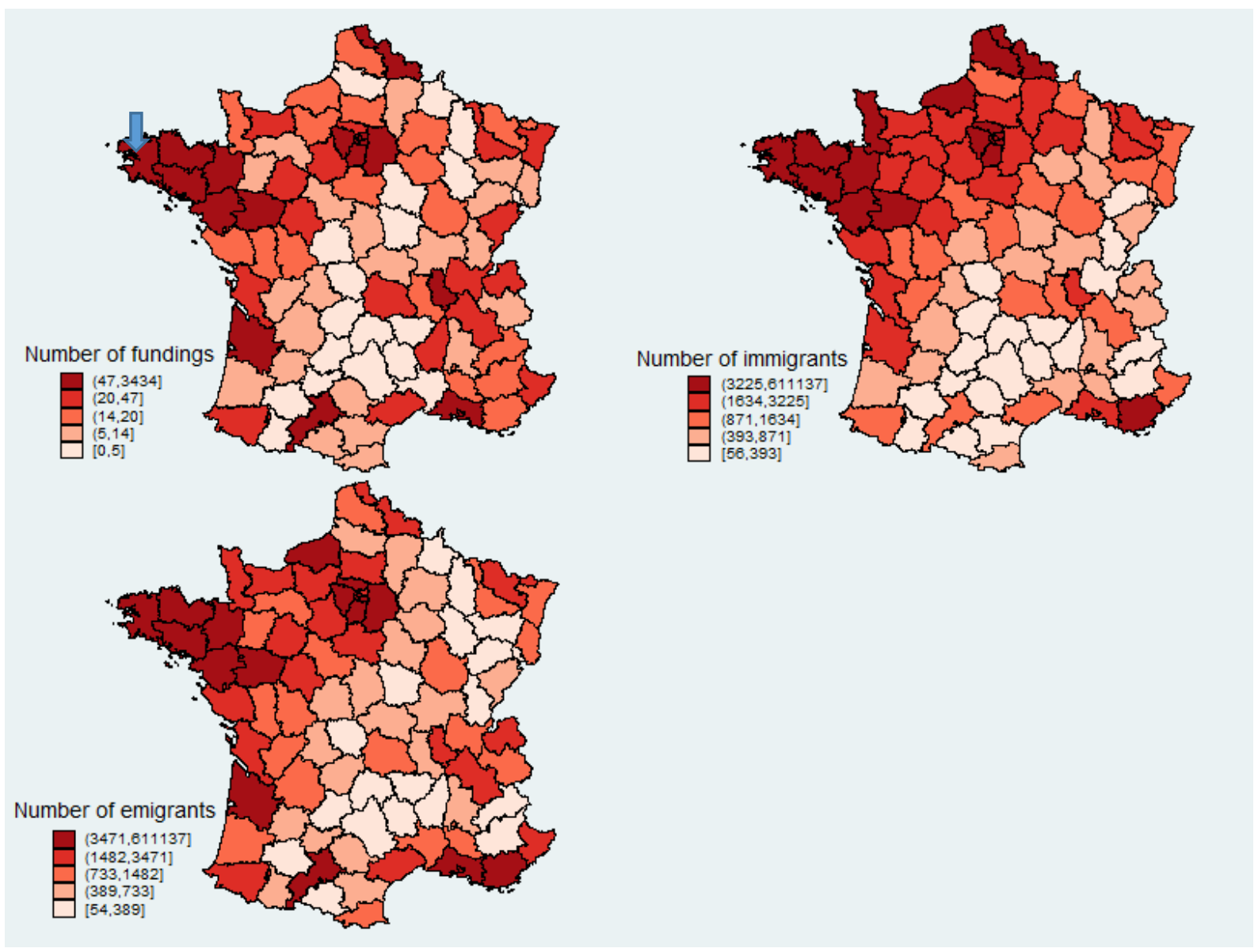


Table 1a: Descriptive statistics of campaigns 2012-2015

All Comics Video Music Charity Stage Pre-order

\begin{tabular}{lccccccc}
\hline Number of projects & 12887 & 293 & 2312 & 1725 & 2542 & 1006 & 262 \\
Mean goal (€) & 3438 & 3443 & 3075 & 2630 & 2692 & 2601 & 13685 \\
Mean amount raised (€) & 3005 & 5494 & 3088 & 2554 & 2361 & 2215 & 6646 \\
Success rate & $74 \%$ & $81 \%$ & $81 \%$ & $82 \%$ & $74 \%$ & $76 \%$ & $73 \%$ \\
Mean backers per project & 56 & 140 & 58 & 55 & 46 & 42 & 123 \\
Mean contribution per backer $(€)$ & 55 & 39 & 53 & 46 & 51 & 53 & 54 \\
Share of intra-regional contributions & $28 \%$ & $12 \%$ & $22 \%$ & $37 \%$ & $30 \%$ & $43 \%$ & $18 \%$ \\
\hline
\end{tabular}

Table $2 \mathrm{~b}$ : Descriptive statistics of variables used in the gravity model

\begin{tabular}{|c|c|c|c|c|c|c|}
\hline VARIABLE & Unit of measurement & Mean & S.D. & Min & Max & Observations \\
\hline DENSITY & Inhabitants per $\mathrm{km}^{2}$ & 572.9 & 2488.6 & 15 & 21154 & 94 \\
\hline$D_{I S T A N C E} i j$ & Kilometer & 404.6 & 196.3 & 7.15 & 1262 & 8836 \\
\hline FUNDING $G_{i j}$ & Number of investments & 33.30 & 119 & 0 & 4564 & 8836 \\
\hline AMOUNT FUNDED $D_{i j}$ & Euros & 1531 & 6138 & 0 & 280007 & 8836 \\
\hline WEALTH & Millions of euros & 139 & 112 & 14 & 576 & 94 \\
\hline CREATIVE & $\begin{array}{l}\% \text { of active population working in the } \\
\text { arts and cultural sector }\end{array}$ & 1.518 & 1.252 & 0.37 & 11.77 & 94 \\
\hline MIGRATION $_{i j}$ & Number of migrants & 2568 & 8670 & 4.04 & 287219 & 8836 \\
\hline
\end{tabular}


Table 2: OLS estimation of bilateral regional funding

\begin{tabular}{|c|c|c|c|c|c|}
\hline VARIABLE & $\begin{array}{c}\operatorname{Ln}\left(F_{i j}\right) \\
(1)\end{array}$ & $\begin{array}{c}\operatorname{Ln}\left(F_{i j}\right) \\
(2)\end{array}$ & $\begin{array}{c}\operatorname{Ln}\left(F_{i j}\right) \\
(3)\end{array}$ & $\begin{array}{c}\operatorname{Ln}\left(F_{i j}\right) \\
(4)\end{array}$ & $\begin{array}{c}\operatorname{Ln}\left(F_{i j}\right) \\
(5)\end{array}$ \\
\hline $\operatorname{Ln}(D I S T A N C E)$ & $\begin{array}{c}-0.520 * * * \\
(0.0161)\end{array}$ & $\begin{array}{c}-0.470 * * * \\
(0.0162)\end{array}$ & $\begin{array}{c}-0.204^{* * *} \\
(0.0190)\end{array}$ & $\begin{array}{c}-0.286 * * * \\
(0.0201)\end{array}$ & $\begin{array}{l}-0.0293 \\
(0.0229)\end{array}$ \\
\hline $\operatorname{Ln}\left(W E A L T H_{i} * W E A L T H_{j}\right)$ & $\begin{array}{l}1.013 * * * \\
(0.00904)\end{array}$ & $\begin{array}{l}0.795^{* * *} \\
(0.0140)\end{array}$ & $\begin{array}{l}0.586 * * * \\
(0.0173)\end{array}$ & $\begin{array}{c}0.652^{* * *} \\
(0.0186)\end{array}$ & $\begin{array}{l}0.450 * * * \\
(0.0207)\end{array}$ \\
\hline $\operatorname{Ln}\left(D E N S I T Y_{i} * D E N S I T Y_{j}\right)$ & & $\begin{array}{c}0.0701^{* * *} \\
(0.00935)\end{array}$ & $\begin{array}{l}0.0703^{* * *} \\
(0.00910)\end{array}$ & $\begin{array}{c}0.0703 * * * \\
(0.00906)\end{array}$ & $\begin{array}{r}0.0705 * * * \\
(0.00894)\end{array}$ \\
\hline $\operatorname{Ln}\left(C R E A T I V_{i} * C R E A T I V_{j}\right)$ & & $\begin{array}{l}0.353^{* * *} \\
(0.0157)\end{array}$ & $\begin{array}{c}0.321 * * * \\
(0.0155)\end{array}$ & $\begin{array}{l}0.331^{* * *} \\
(0.0155)\end{array}$ & $\begin{array}{l}0.300 * * * \\
(0.0153)\end{array}$ \\
\hline $\operatorname{Ln}\left(M I G R O R I_{i j}\right)$ & & & $\begin{array}{l}0.240 * * * \\
(0.0127)\end{array}$ & & $\begin{array}{l}0.237 * * * \\
(0.0123)\end{array}$ \\
\hline $\operatorname{Ln}\left(M I G R D E S T_{j i}\right)$ & & & & $\begin{array}{l}0.165^{* * *} \\
(0.0135)\end{array}$ & $\begin{array}{l}0.161 * * * \\
(0.0129)\end{array}$ \\
\hline Constant & $\begin{array}{c}-41.41 * * * \\
(0.429)\end{array}$ & $\begin{array}{c}-32.49 * * * \\
(0.576)\end{array}$ & $\begin{array}{c}-26.00 * * * \\
(0.658)\end{array}$ & $\begin{array}{c}-28.02^{* * *} \\
(0.700)\end{array}$ & $\begin{array}{c}-21.76 * * * \\
(0.751)\end{array}$ \\
\hline Observations & 8,742 & 8,742 & 8,742 & 8,742 & 8,742 \\
\hline R-squared & 0.627 & 0.656 & 0.670 & 0.663 & 0.677 \\
\hline
\end{tabular}

Robust standard errors in parentheses

$* * * p<0.01, * * p<0.05, * p<0.1$ 
Table 3: OLS estimation of bilateral regional funding with intra-regional investment

\begin{tabular}{|c|c|c|c|c|c|}
\hline VARIABLE & $\begin{array}{c}\operatorname{Ln}\left(F_{i j}\right) \\
(1)\end{array}$ & $\begin{array}{c}\operatorname{Ln}\left(\mathrm{F}_{\mathrm{ij}}\right) \\
(2)\end{array}$ & $\begin{array}{c}\operatorname{Ln}\left(F_{i j}\right) \\
(3)\end{array}$ & $\begin{array}{c}\operatorname{Ln}\left(\mathrm{F}_{\mathrm{ij}}\right) \\
(4)\end{array}$ & $\begin{array}{c}\operatorname{Ln}\left(F_{i j}\right) \\
(5)\end{array}$ \\
\hline $\operatorname{Ln}(D I S T A N C E)$ & $\begin{array}{c}-0.520^{* * *} \\
(0.0161)\end{array}$ & $\begin{array}{c}-0.471^{* * *} \\
(0.0161)\end{array}$ & $\begin{array}{c}-0.197^{* * *} \\
(0.0190)\end{array}$ & $\begin{array}{c}-0.279 * * * \\
(0.0201)\end{array}$ & $\begin{array}{l}-0.0207 \\
(0.0227)\end{array}$ \\
\hline $\operatorname{Ln}\left(W_{E A L T H} * W_{i} A L T H_{j}\right)$ & $\begin{array}{l}1.006^{* * *} \\
(0.00900)\end{array}$ & $\begin{array}{l}0.794^{* * *} \\
(0.0140)\end{array}$ & $\begin{array}{l}0.581^{* * *} \\
(0.0172)\end{array}$ & $\begin{array}{l}0.645^{* * *} \\
(0.0184)\end{array}$ & $\begin{array}{l}0.444^{* * *} \\
(0.0204)\end{array}$ \\
\hline $\operatorname{Ln}\left(D E N S I T Y_{i} * D E N S I T Y_{j}\right)$ & & $\begin{array}{l}0.0654^{* * *} \\
(0.00947)\end{array}$ & $\begin{array}{l}0.0661 * * * \\
(0.00913)\end{array}$ & $\begin{array}{l}0.0659 * * * \\
(0.00912)\end{array}$ & $\begin{array}{l}0.0666^{* * *} \\
(0.00892)\end{array}$ \\
\hline $\operatorname{Ln}\left(C R E A T I V_{i} *{ }^{*} R E A T I V_{j}\right)$ & & $\begin{array}{l}0.353^{* * *} \\
(0.0156)\end{array}$ & $\begin{array}{l}0.321 * * * \\
(0.0153)\end{array}$ & $\begin{array}{c}0.330 * * * \\
(0.0153)\end{array}$ & $\begin{array}{c}0.299 * * * \\
(0.0151)\end{array}$ \\
\hline $\operatorname{Ln}\left(M I G R O R I_{i j}\right)$ & & & $\begin{array}{c}0.247^{* * *} \\
(0.0127)\end{array}$ & & $\begin{array}{l}0.241^{* * *} \\
(0.0122)\end{array}$ \\
\hline $\operatorname{Ln}\left(M I G R D E S T_{j i}\right)$ & & & & $\begin{array}{c}0.173^{* * *} \\
(0.0134)\end{array}$ & $\begin{array}{c}0.165^{* * *} \\
(0.0128)\end{array}$ \\
\hline HOME & $\begin{array}{c}0.996^{* * *} \\
(0.131)\end{array}$ & $\begin{array}{c}1.283^{* * *} \\
(0.132)\end{array}$ & $\begin{array}{c}1.460 * * * \\
(0.117)\end{array}$ & $\begin{array}{c}1.407^{* * *} \\
(0.120)\end{array}$ & $\begin{array}{c}1.575^{* * *} \\
(0.111)\end{array}$ \\
\hline Constant & $\begin{array}{c}-41.06^{* * *} \\
(0.428)\end{array}$ & $\begin{array}{c}-32.37^{* * *} \\
(0.575)\end{array}$ & $\begin{array}{c}-25.79 * * * \\
(0.652)\end{array}$ & $\begin{array}{c}-27.76^{* * *} \\
(0.692)\end{array}$ & $\begin{array}{c}-21.55^{* * *} \\
(0.739)\end{array}$ \\
\hline Observations & 8,836 & 8,836 & 8,836 & 8,836 & 8,836 \\
\hline R-squared & 0.653 & 0.680 & 0.694 & 0.687 & 0.701 \\
\hline
\end{tabular}

Robust standard errors in parentheses

${ }^{* * *} p<0.01,{ }^{* *} p<0.05, * p<0.1$ 
Table 4: Fixed-effects estimation of bilateral regional funding

\begin{tabular}{|c|c|c|c|c|}
\hline \multirow[b]{2}{*}{ VARIABLE } & \multicolumn{2}{|c|}{$\begin{array}{c}\text { Without intra-regional } \\
\text { funding }\end{array}$} & \multicolumn{2}{|c|}{$\begin{array}{l}\text { With intra-regional } \\
\text { funding }\end{array}$} \\
\hline & $\begin{array}{c}\operatorname{Ln}\left(F_{i j}\right) \\
(1)\end{array}$ & $\begin{array}{c}\operatorname{Ln}\left(F_{i j}\right) \\
(2)\end{array}$ & $\begin{array}{c}\operatorname{Ln}\left(F_{i j}\right) \\
(3)\end{array}$ & $\begin{array}{c}\operatorname{Ln}\left(F_{i j}\right) \\
(4)\end{array}$ \\
\hline $\operatorname{Ln}(D I S T A N C E)$ & $\begin{array}{c}-0.564 * * * \\
(0.0132)\end{array}$ & $\begin{array}{c}-0.0611^{* * *} \\
(0.0164)\end{array}$ & $\begin{array}{c}-0.551^{* * *} \\
(0.0141)\end{array}$ & $\begin{array}{c}-0.0476 * * * \\
(0.0174)\end{array}$ \\
\hline $\operatorname{Ln}\left(M / G R O R l_{i j}\right)$ & & $\begin{array}{l}0.251^{* * *} \\
(0.0214)\end{array}$ & & $\begin{array}{l}0.257^{* * *} \\
(0.0215)\end{array}$ \\
\hline $\operatorname{Ln}\left(M I G R D E S T_{j i}\right)$ & & $\begin{array}{l}0.164^{* * *} \\
(0.0219)\end{array}$ & & $\begin{array}{l}0.170 * * * \\
(0.0220)\end{array}$ \\
\hline HOME & & & $\begin{array}{c}0.932 * * * \\
(0.143)\end{array}$ & $\begin{array}{l}1.304^{* * *} \\
(0.0914)\end{array}$ \\
\hline Constant & $\begin{array}{c}8.097 * * * \\
(0.116)\end{array}$ & $\begin{array}{c}2.593 * * * \\
(0.194)\end{array}$ & $\begin{array}{c}8.031 * * * \\
(0.120)\end{array}$ & $\begin{array}{c}2.412^{* * *} \\
(0.198)\end{array}$ \\
\hline Fixed effects & YES & YES & YES & YES \\
\hline Observations & 8,742 & 8,742 & 8,836 & 8,836 \\
\hline R-squared & 0.864 & 0.880 & 0.870 & 0.888 \\
\hline
\end{tabular}

Robust standard errors in parentheses

$* * * p<0.01, * * p<0.05, * p<0.1$ 
Table 5: Estimation of bilateral funding for different categories of projects

\begin{tabular}{lllllll}
\hline & $\operatorname{Ln}\left(F_{i j}\right)$ & $\operatorname{Ln}\left(F_{i j}\right)$ & $\operatorname{Ln}\left(F_{i j}\right)$ & $\operatorname{Ln}\left(F_{i j}\right)$ & $\operatorname{Ln}\left(F_{i j}\right)$ & $\operatorname{Ln}\left(F_{i j}\right)$ \\
VARIABLES & Comics & Video & Music & Charity & Stage & Pre-order
\end{tabular}
(1)
(2)
(3)
(4)
(5)
(6)

\begin{tabular}{|c|c|c|c|c|c|c|}
\hline \multirow[t]{2}{*}{$\operatorname{Ln}(D I S T A N C E)$} & $-0.109 * * *$ & $-0.0966 * * *$ & $-0.222 * * *$ & $-0.0621 * * *$ & $-0.153 * * *$ & -0.0129 \\
\hline & $(0.0291)$ & $(0.0290)$ & $(0.0217)$ & $(0.0239)$ & $(0.0222)$ & $(0.0300)$ \\
\hline \multirow[t]{2}{*}{$\operatorname{Ln}\left(W E A L T H_{i} * W E A L T H_{j}\right)$} & $0.317^{* * *}$ & $0.133^{* * *}$ & $0.154 * * *$ & $0.220 * * *$ & 0.0193 & $0.118 * * *$ \\
\hline & $(0.0221)$ & $(0.0241)$ & (0.0199) & (0.0198) & $(0.0167)$ & $(0.0219)$ \\
\hline \multirow[t]{2}{*}{$\operatorname{Ln}\left(D E N S I T Y_{i} * D E N S I T Y_{j}\right)$} & $0.114 * * *$ & $0.187^{* * *}$ & $0.0842 * * *$ & $0.0757 * * *$ & $0.105^{* * *}$ & $0.114^{* * *}$ \\
\hline & $(0.0121)$ & $(0.0118)$ & $(0.00916)$ & $(0.00967)$ & $(0.00869)$ & $(0.0118)$ \\
\hline \multirow[t]{2}{*}{$\operatorname{Ln}\left(C R E A T I V_{i} * C^{*} E A T I V_{j}\right)$} & $0.134 * * *$ & $0.177^{* * *}$ & $0.216^{* * *}$ & $0.248 * * *$ & $0.195 * * *$ & $0.152 * * *$ \\
\hline & $(0.0155)$ & $(0.0161)$ & $(0.0131)$ & (0.0139) & (0.0108) & $(0.0157)$ \\
\hline \multirow[t]{2}{*}{$\operatorname{Ln}\left(M I G R O R I_{i j}\right)$} & $0.0284 * *$ & $0.0952 * * *$ & $0.0769 * * *$ & $0.105^{* * *}$ & $0.0392 * * *$ & 0.0205 \\
\hline & (0.0119) & (0.0139) & $(0.0113)$ & $(0.0118)$ & $(0.00910)$ & $(0.0127)$ \\
\hline \multirow[t]{2}{*}{$\operatorname{Ln}\left(M I G R D E S T_{j i}\right)$} & -0.00191 & $0.0812^{* * *}$ & $0.160 * * *$ & $0.129 * * *$ & $0.0525^{* * *}$ & $0.0609 * * *$ \\
\hline & $(0.0124)$ & $(0.0135)$ & $(0.0111)$ & $(0.0111)$ & $(0.00893)$ & $(0.0121)$ \\
\hline \multirow[t]{2}{*}{ HOME } & $0.817^{* * *}$ & $1.403 * * *$ & $1.041^{* * *}$ & $1.733^{* * *}$ & $1.464 * * *$ & $0.923 * * *$ \\
\hline & $(0.187)$ & $(0.163)$ & $(0.151)$ & $(0.144)$ & $(0.176)$ & $(0.202)$ \\
\hline \multirow[t]{2}{*}{ Constant } & $-14.68 * * *$ & $-7.826^{* * *}$ & $-7.487^{* * *}$ & $-11.29 * * *$ & $-1.370^{* *}$ & $-6.580 * * *$ \\
\hline & $(0.791)$ & $(0.852)$ & $(0.713)$ & $(0.707)$ & $(0.587)$ & $(0.775)$ \\
\hline Observations & 8,836 & 8,836 & 8,836 & 8,836 & 8,836 & 8,836 \\
\hline R-squared & 0.388 & 0.461 & 0.576 & 0.557 & 0.487 & 0.287 \\
\hline Number of proje & 293 & 2312 & 1725 & 2542 & 1006 & 262 \\
\hline
\end{tabular}

Robust standard errors in parentheses

$* * * p<0.01, * * p<0.05, * p<0.1$ 
Table 6: Estimation with the amount of bilateral funding as the dependent variable

\begin{tabular}{|c|c|c|c|}
\hline VARIABLE & $\begin{array}{c}\operatorname{Ln}\left(A_{i j}\right) \\
(1)\end{array}$ & $\begin{array}{c}\operatorname{Ln}\left(A_{i j}\right) \\
(2)\end{array}$ & $\begin{array}{c}\operatorname{Ln}\left(A_{i j}\right) \\
(3)\end{array}$ \\
\hline $\operatorname{Ln}(D I S T A N C E)$ & $\begin{array}{c}-0.744^{* * *} \\
(0.0272)\end{array}$ & $\begin{array}{l}-0.0191 \\
(0.0407)\end{array}$ & $\begin{array}{l}0.00794 \\
(0.0345)\end{array}$ \\
\hline $\operatorname{Ln}\left(W E A L T H_{i} * W E A L T H_{j}\right)$ & $\begin{array}{l}1.500^{* * *} \\
(0.0167)\end{array}$ & $\begin{array}{l}0.794 * * * \\
(0.0359)\end{array}$ & \\
\hline $\operatorname{Ln}\left(D E N S I T Y_{i} * D E N S I T Y_{j}\right)$ & & $\begin{array}{c}-0.00343 \\
(0.0143)\end{array}$ & \\
\hline $\operatorname{Ln}\left(C R E A T I V_{i} * C^{*} E A T I V_{j}\right)$ & & $\begin{array}{l}0.423 * * * \\
(0.0304)\end{array}$ & \\
\hline $\operatorname{Ln}\left(M I G R O R I_{i j}\right)$ & & $\begin{array}{l}0.367^{* * *} \\
(0.0230)\end{array}$ & $\begin{array}{c}0.458^{* * *} \\
(0.0495)\end{array}$ \\
\hline $\operatorname{Ln}\left(M I G R D E S T_{j i}\right)$ & & $\begin{array}{l}0.245^{* * *} \\
(0.0238)\end{array}$ & $\begin{array}{c}0.234^{* * *} \\
(0.0503)\end{array}$ \\
\hline HOME & $\begin{array}{l}0.489 * * \\
(0.222)\end{array}$ & $\begin{array}{c}1.205^{* * *} \\
(0.181)\end{array}$ & $\begin{array}{c}0.902^{* * *} \\
(0.172)\end{array}$ \\
\hline Constant & $\begin{array}{c}-59.45^{* * *} \\
(0.787)\end{array}$ & $\begin{array}{c}-35.43^{* * *} \\
(1.323)\end{array}$ & $\begin{array}{c}5.162^{* * *} \\
(0.373)\end{array}$ \\
\hline Fixed-effects & NO & NO & YES \\
\hline Observations & 8,836 & 8,836 & 8,836 \\
\hline R-squared & 0.537 & 0.571 & 0.759 \\
\hline
\end{tabular}

Robust standard errors in parentheses

$* * * p<0.01, * * p<0.05, * p<0.1$ 
Table 7: OLS estimation of bilateral regional funding excluding the Ile-de-France region

\begin{tabular}{|c|c|c|c|}
\hline VARIABLE & $\begin{array}{c}\operatorname{Ln}\left(\mathrm{F}_{\mathrm{ij}}\right) \\
(1)\end{array}$ & $\begin{array}{c}\operatorname{Ln}\left(\mathrm{F}_{\mathrm{ij}}\right) \\
(2)\end{array}$ & $\begin{array}{c}\operatorname{Ln}\left(\mathrm{F}_{\mathrm{ij}}\right) \\
(3)\end{array}$ \\
\hline $\operatorname{Ln}(D I S T A N C E)$ & $\begin{array}{c}-0.624^{* * *} \\
(0.0190)\end{array}$ & $\begin{array}{c}-0.593^{* * *} \\
(0.0189)\end{array}$ & $\begin{array}{c}-0.109 * * * \\
(0.0327)\end{array}$ \\
\hline $\operatorname{Ln}\left(W E A L T H_{i} * W E A L T H_{j}\right)$ & $\begin{array}{l}0.956^{* * *} \\
(0.0102)\end{array}$ & $\begin{array}{c}0.900 * * * \\
(0.0204)\end{array}$ & $\begin{array}{c}0.564 * * * \\
(0.0284)\end{array}$ \\
\hline $\operatorname{Ln}\left(D E N S I T Y_{i} * D E N S I T Y_{j}\right)$ & & $\begin{array}{l}-0.0350 \\
(0.0214)\end{array}$ & $\begin{array}{l}-0.0336 \\
(0.0210)\end{array}$ \\
\hline $\operatorname{Ln}\left(C R E A T I V_{i} * C R E A T I V_{j}\right)$ & & $\begin{array}{l}0.281^{* * *} \\
(0.0172)\end{array}$ & $\begin{array}{c}0.259 * * * \\
(0.0168)\end{array}$ \\
\hline $\operatorname{Ln}\left(M I G R O R I_{i j}\right)$ & & & $\begin{array}{c}0.241^{* * *} \\
(0.0139)\end{array}$ \\
\hline $\operatorname{Ln}\left(M I G R D E S T_{j i}\right)$ & & & $\begin{array}{c}0.128^{* * *} \\
(0.0146)\end{array}$ \\
\hline HOME & $\begin{array}{c}0.538^{* * *} \\
(0.138)\end{array}$ & $\begin{array}{c}0.716^{* * *} \\
(0.136)\end{array}$ & $\begin{array}{c}1.372^{* * *} \\
(0.129)\end{array}$ \\
\hline Constant & $\begin{array}{c}-38.20^{* * *} \\
(0.464)\end{array}$ & $\begin{array}{c}-35.60^{* * *} \\
(0.787)\end{array}$ & $\begin{array}{c}-25.40 * * * \\
(0.992)\end{array}$ \\
\hline Observations & 7,396 & 7,396 & 7,396 \\
\hline R-squared & 0.609 & 0.622 & 0.640 \\
\hline
\end{tabular}

Robust standard errors in parentheses

${ }^{* * *} p<0.01,{ }^{* *} p<0.05,{ }^{*} p<0.1$ 
Table 8: Comparison of subsamples with and without location of contributors

\begin{tabular}{ccccc}
\hline Group & Obs. & Mean & Std. Err. & Std. Dev. \\
\hline Without location & 279836 & 46.03 & .20 & 106.2 \\
With location & 452850 & 45.93 & .13 & 91.3 \\
& & & & \\
Combined & 732686 & 45.971 & .113708 & 97.33 \\
& & & & \\
Difference & & .1068415 & .2340347 & \\
\hline
\end{tabular}

* Significant at $1 \%$ 
Table 9: Correlation matrix

\begin{tabular}{cccccccc}
\hline & & $(1)$ & $(2)$ & $(3)$ & $(4)$ & $(5)$ & $(6)$ \\
\hline$(1)$ & DISTANCE & 1 & & & & & \\
$(2)$ & WEALTH & $0.047^{*}$ & 1 & & & & \\
$(3)$ & DENSITY & $-0.048^{*}$ & $0.55^{*}$ & 1 & & & \\
$(4)$ & CREATIV & $-0.037^{*}$ & $0.635^{*}$ & $0.849 *$ & 1 & & \\
$(5)$ & MIGRORI & $-0.24^{*}$ & $0.212^{*}$ & 0.134 & $0.139^{*}$ & 1 & \\
$(6)$ & MIGRDEST & $-0.24^{*}$ & $0.28^{*}$ & $0.312^{*}$ & $0.298^{*}$ & $0.617^{*}$ & 1 \\
\hline
\end{tabular}

